\title{
Supporting of Children with Special Needs in Inclusive Environment by the Teachers Collaboration
}

Tetiana Skrypnyk ${ }^{1}$, Olena Martynchuk ${ }^{2}$, Olha Klopota ${ }^{3}$, Vytautas Gudonis ${ }^{4}$, Nataliia Voronska ${ }^{5}$

1 Borys Grinchenko Kyiv University, Institute of Human Sciences, 18/2 Bulvarno-Kudriavska St., UA-04053 Kyiv, Ukraine, dr.skrypnyk@gmail.com

2 Borys Grinchenko Kyiv University, Institute of Human Sciences, 18/2 Bulvarno-Kudriavska St., UA-04053 Kyiv, Ukraine, o.martynchuk@kubg.edu.ua

3 Khortytsia National Academy, 59 Naukove Mistechko St. (Khortytsia Island), UA-69017 Zaporizhzhia, Ukraine, oa-klopota@ukr.net

4 Siauliai University, Institute of Education, 25 P. Visinskio St., LT-76353 Siauliai, Lithuania, gudonis@su.lt

5 Zaporizhzhia National University, 66 Zhukovskogo St., Zaporizhzhia, UA-69600, Ukraine, natalyvoronska@ukr.net

\begin{abstract}
This article reveals the features of effective teamwork (teachers, specialists, parents) in management, training in working with children with special needs, in a general education school. To achieve positive results when working with children with special needs in mainstream schools, educators must have sufficient teamwork skills. The results of the study confirmed the effectiveness of the developed pedagogical, and psychological program for the optimization of command control and interaction.
\end{abstract}

Keywords: teacher's competence, inclusion, children with special needs, team cooperation.

\section{Introduction}

Today there is a typical situation when teachers of inclusive classes do not coordinate between them the goals of a child with special needs development, they use different procedures, methods, and means for his supporting; they do not find the correct balance between education and rehabilitation services for children with special needs; they do not conduct the monitoring of supporting process in Ukraine. 
The implementation of inclusive education is a complicated task because it must be well-thought-out, prepared, and based on pointed efficiency factors. Skilled inclusive classes teachers create the necessity of constant need for administrative support, time scheduling, and the opportunity for career development (Blecker and Boakes, 2010). As the result of analysis of successful inclusive classes practice it is determined that apart from positive attitude the teachers should have appropriate the competence which includes: 1) the ability to adapt the physical environment in classes, the program and the methods of education according to different children's needs; 2) to overwhelm the technology of effective class management (Capp, 2017; Corps, 2008; Wong, 2014); 3) to be able to work in a team (Hackman, 2002; Stroggilos, 2006).

The scientists consider the ability to pay attention to the development of the teachers' capability to organise the education process based on partnership, the ability to communicate with colleagues, students and parents to be the qualities of effective teachers (Kurth, 2014; Rotte, 2014 ects.). A meta-analystic study (Hattie, 2009) emphasise that "Teacher Collaboration" foresees the unification of teachers' potential which has different types: training the teachers one by one, joint discussion and planning, the determination of education intentions, success criteria, learning progress, children's expectations.

The investigations show the ways of improving team cooperation in the developmental process of Individualized Education Program (IEP): the correct formulation of goals (transition from different personal goals for each professional to common goal for each member of the support team to work at); compulsory participation of parents for the determination and the reliability of the goals (Stroggilos, 2006); the improvement of IEP structure, as well as writing some more useful information for the teachers who work directly with a child with special needs (Rotte, 2014).

Among disadvantages of such a type of collaboration, there is a co-teaching technology, namely that teachers of inclusive classes, who have to use it, do not pay enough attention to the planning of cooperation and the evaluation of its progress, herewith there is a tendency to work alone, not in a team (Stroggilos, 2016).

The scientists point out the critical importance of teachers' ability to participate in a team for developing programs for children of inclusive classes and in works which are focused on the improvement and the evaluation of these programs (İlik, 2017).

\section{Theoretical background}

A number of studies (Hattie, 2009; Wong, 2014 and etc.) prove that not material support, but teachers' achievements at the level of expert improve children's achievements thanks to which they have a great number of strategies: they are able to organise the educational process and to provide its content in the best way; they can connect new knowledge with previous one, the topic of their lesson with other subject areas, they can 
adapt the lessons to the children's needs, they can create the atmosphere of trust and success based on their persuasion that all the children can achieve the certain success criteria for them. It also provides a careful analysis of success and failure factors that cause the further improvement of their own educational strategies. An important component of such work is feedback with students.

Team cooperation in the teachers' work is important because the educational process has an environment context just because the performance level of education and the children's development depend on a created atmosphere by teachers. According to Vygotsky, the social environment is a set of human relationships, a certain method of bringing up (Vygotsky, 1996).

The educational environment is often considered to be a system of influences and conditions which ensure the realization of educational process (Boser, 2014; Klopota, 2017). It is also said that in order to increase the effectiveness of teaching and educational process for children with SEN (Special Education Needs) certain adaptive changes such as additional specific group of conditions (Curtis, Leach etc.) can be used. These conditions cause prophylaxis of undesired consequences among children with SEN driven by the special aspects of their psychophysical development.

The publications of recent years, in which the question is about effective teachers leadup to inclusive education of the children with SEN, show multifarious programs of their helping and supporting which increase the ability of inclusive education. In the developments of recent years, foreign researchers focus on: the necessity of using the methods with scientifically proven effectiveness (Carrero, 2014; Mesibov, 2010); the improvement of supporting documentation for the inclusive process taking into account certain children development goals (Bateman, 2003); the development and the realization of such strategies for successful inclusion as: the implementation of universal design (Al-Azawei, 2017; Capp, 2013); the development of the methods of influence and evaluative tooling that meet special educational children's needs (Boser, 2014).

\section{Methodology of Research}

The object of this study is a team collaboration of teachers in the process of supporting children with special needs.

It was conducted an experimental research in four cities of Ukraine: Kyiv, Bila Tserkva, Poltava and Chernihiv. The purpose is to create and to implement the scheme of increasing the inclusive classes teachers' competence. It implies using mastered teachers' skills directly in their professional situation based on the model of team management for significant achievements (R. Hackman) and with continued support from expert coaching. 


\section{This was done in stages}

1. The preparatory stage: an empirical study of mastery of teachers in using of the strategy of team support of the educational process of children with special needs.

2. The main stage: creation and implementation of educational program aimed at increasing the ability of teachers to work in an interdisciplinary team to support children with special needs.

3. The completion stage: repeated empirical study to analysis the effectiveness of the created and implemented program.

The participants were 152 teachers from 17 educational institutions, 129 people (85\%) were women and 23 ones (15\%) were men. Selected teachers were chosen using random selection method. The great amount of all the teachers were 121 people $(79,6 \%)$ who had experience in teaching students with special needs; others were aware that such children would come to their class in the nearest future.

The consent was obtained from all participants in our research.

\section{Results}

The first (preparatory) stage: an empirical study of mastery of teachers in using of the strategy of team support of the educational process of children with special needs

At the first stage of research, we have conducted a study of mastery of teachers in using a socio- psychological group of resources, especially - their understanding of the strategy of team support of the educational process of children with special needs, the role of each team member and their place in this process.

\section{Instruments and Procedures}

To determine the teachers' competence regarding interdisciplinary team supporting we used the following methods:

- The semi-structured questionnaire, developed by us.

- The method for the determination of teachers' self-concept "Professional Development Tool".

- The "Test of motivational orientations" Method (“TOM”, Borgogni, Petita, Barbaranelli, 2008).

The semi-structured questionnaire developed by us that met the previously planned interview protocol and made it possible to obtain more systematic comparative data.

Each interview lasted 25 to $40 \mathrm{~min}$. At the beginning of the interview, each teacher was informed about the purpose of the questioning. So, it was said that the questioning will determine how teachers can be assisted to conduct the process of supporting children with SEN: what are their needs in connection with the fact that there is a student 
with SEN in the class; which methods do they use; due to what, in their opinion, they are successful; how they interact with other colleagues, which function each member of the support team has what is the form of their cooperation with parents of children's with SEN etc.

The interviews were recorded using the voice recorder, and then these records were decoded. The obtained data was analysed and interpreted according to the determined priorities to the percentage and the content analysis method.

The semi-structured interview determined that most teachers $(\mathrm{n}=104,68 \%)$ complained about the discrepancy between the requirements which are put forward by the government (regarding the environment design, the usage of the modern facilities, the renovation of the education space) and about the lack of financial support of this process.

Many teachers ( $n=73,48 \%)$ agreed that it would be easier for them to work with the help of correction-developmental specialists (speech therapists, special education teachers, practical psychologists). Some teachers (39\%) found out the lack of desire, firstly, to distribute educational strategies and to teach together with another teacher (who is called teacher's assistant according to the Ukrainian government, and who actually serves as a "teacher of special education"); 64\% of the interviewed teachers (n=98\%) did not show any desire to cooperate with parents on a partnership basis (that is, it was found out that the current state of partnership with the parents satisfies them, the state in which the parents are the performers of teacher's tasks and recommendations, herewith they do not have any right to make decisions and they also affect nothing). This situation indicates the outdated teacher's position which is characterised by authoritarianism and the desire to manage the whole situation of learning independently.

The Method for the determination of teachers' self-concept "Professional Development Tool for Improving the Quality of Practice in primary school”, developed in 2008 under the activities of International Association of Teachers called "ISSA" - International Step by Step Association (henceforth we will call this method "Tool ISSA"). This method comprises seven target industries under which the main parameters of modern high-quality teaching are concretized and the ways of achievement professional skills are determined. In this method, there are determined the indicators of the quality according to different parameters and there is a grading scale: 0 - "unsatisfying", 1 - "a good start", 2 - "a good practice of work", 3 - "the level of improvement (how to move forward) ".

Summarized results of the questionnaire using the "Tool ISSA" method found the following levels of formed teachers' competence in different target industries:

- "Unsatisfying practice" (non-child-oriented practice work) included 36.2\% of teachers in 6 target industries: Interactions, Family and Community, Inclusion, Assessment and Planning, Teaching strategies, Learning Environment;

- "Good start" (teachers' efforts to master effective and practical work methods aimed at the children) included $50 \%$ of teachers; 
- Between two valuations: "Good start" and "Good work practice" (the faith in the children's potential, stable successful practice, the usage of all opportunities for raising the professional level) included $13.2 \%$ of teachers.

Six educational institutions had an overall "Good Start" valuations, in which teachers had the opportunity to learn effective methods, techniques and methods of practical work aimed at children, and three educational institutions worked between two valuations: "Good start" and "Quality work practices" in which teachers believe in the children's potential, have a stable successful work practice while using all the opportunities to increase their own professional level.

The "Test of motivational orientations" method ("TOM", Borgogni, Petita, Barbaranelli, 2008) aimed at the identifying the tendencies of person's motivational sphere in professional conditions using the method of self-examination in a professional setting.

The TOM method helped to understand what kind of motivational orientations teachers prefer, namely the identification of their important personality traits as aspiration, need in success, and ability to self-examine. Responding 70 statements, the teachers gave the answers which were evaluated by the 7-point Likert's scale (1="completely disagree"; 2 =»almost disagree"; $3=$ "partially disagree"; $4=$ "I can neither agree nor disagree"; $5=$ "partially agree"; $6=$ "almost agree"; $7=$ "completely disagree"). Testing and processing of the results were conducted with the help of the automated evaluation system "the Internet-test". We will comment on the indicators based on motivational orientations such as: achievement and novelty orientations.

The average test result on a "Motivational Achievement Orientation" indicates that the prevailing level is the average (48-T points) that show precarious activity, apprehension of risk and additional responsibilities, well-minded prediction of self-interests.

The analysis of the teachers' distribution according to the levels of their formation "Motivational orientation to novelty" showed that: $13 \%$ of them showed very low level, $35.5 \%$ of people was at the low level, $39 \%$ of people were at the average level, $12 \%$ of people was at high and none was very high level).

The main stage: creation and implementation of educational program aimed at increasing the ability of teachers to work in an interdisciplinary team to support children with special needs.

The great disadvantage of the inclusive class teacher's work was that they did not monitor the dynamics of children's development. But only conducted questioning of students, they evaluated students' answers and written assignments, they observed students' changes. The impression is that inclusive educational institution teachers have confusion and lack of confidence in the content of their activities in relation to students with SEN. In general, the negative attitude towards the meetings of the support team was also found: the majority of teachers referred to the escort teams meetings as to the forced procedure, saying that it is difficult for them to find the time for the meetings; they 
would prefer to prepare for the next working day or to complete the training documentation. This indicates a low organization level of these meetings, their unpreparedness, and unproductivity of performance.

By analyzing the learning and development dynamics of students with SENs in the classes where examined teachers' work, we can say that the weak ability of teachers to interact in a team mode badly affects the student support process, as the result, the accompanying documents (first of all, IER) are not developed at all, or there are only formal documents which are necessary for the report (and not for practitioners); the objectives of the student's education and development do not reflect their actual situation: they are formulated not in accordance with its current state and are not agreed with all adults, teachers, and parents concerning a child.

Criteria for successfull work of teachers (Hattie, 2009):

1. Prior Achievement: The levels of students at the start.

2. Targeted Learning: The desired levels at the end.

3. Progression: The rate of progress from the beginning to the end.

4. Teacher Collaboration.

For all the teachers selected for an experiment from 17 educational institutions, comprehensive training was provided under the training program called "Teamwork technology of inclusive institutions teachers" and aimed at the formation of professional competences in accordance with the ability to meet the social needs of children with SEN, to form social roles and social relations.

We developed an educational program called "Inclusive teachers team cooperation technology" based on the Model of the Effective Management by Hackman (2002), aimed at assimilating the stages of getting success in supporting students with special needs.

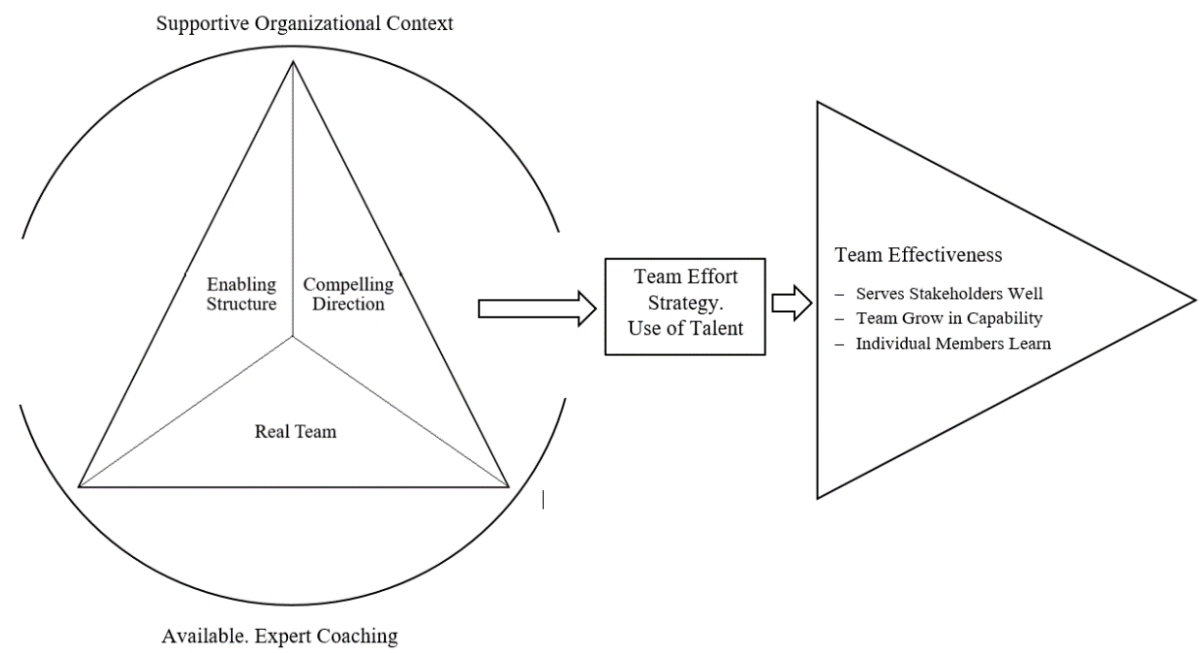

Figure 1. Model of Team Effective Management (R. Hackman) 
According to the model, it becomes clear that the specialists do not have any competencies and want something together. It is important to realize that without the first stage (the creation of a real team and the establishment of its work providing constant expert mentoring), all efforts of the specialists can be a false start, because only previous work that involves thoughtfulness, adoption of joint decisions and a coherent algorithm of actions will enable the successful implementation of existing teachers' competencies, as well as strive to improve their skills in the future 1.

The table 1 below shows the components of the Team Management Model for Significant Achievements.

\section{Table 1}

The Components of the Team Management Model

\begin{tabular}{|c|c|}
\hline Model Component & Content of the Model Component \\
\hline \multirow{3}{*}{$\begin{array}{l}\text { 1. Existing structure (stable } \\
\text { team composition) }\end{array}$} & Rules of team work; \\
\hline & Team boundaries; \\
\hline & Feedback. \\
\hline \multirow[t]{2}{*}{ 2. Steadfast orientation } & $\begin{array}{l}\text { Collegiate goals are relevant for the child; actions to achieve } \\
\text { them are consistent; }\end{array}$ \\
\hline & $\begin{array}{l}\text { The support team knows about their contribution for both the } \\
\text { child and the educational institution. }\end{array}$ \\
\hline \multirow[t]{3}{*}{ 3. A real team } & Common affairs and common tasks, \\
\hline & Responsibility, \\
\hline & Reporting. \\
\hline \multirow[t]{2}{*}{$\begin{array}{l}\text { 4. Favorable organizational } \\
\text { context }\end{array}$} & $\begin{array}{l}\text { Access to data required for work (including professional de- } \\
\text { velopment / competence); }\end{array}$ \\
\hline & Technological assistance and provision of material resources. \\
\hline \multirow[t]{4}{*}{$\begin{array}{l}\text { 5. Systematic expert coaching } \\
\text { (mentoring and training) }\end{array}$} & $\begin{array}{l}\text { Consistent application of integrated knowledge to increase } \\
\text { the competence. }\end{array}$ \\
\hline & Confidence; \\
\hline & Communication; \\
\hline & Interaction of the members of the support team. \\
\hline
\end{tabular}

The presented components of the model are generalized to the following phases of development of effective team interaction:

The 1st phase covers such components as: "existing structure", "steadfast orientation", "real team"). Successful implementation of these components is possible only with "systematic expert coaching". This creates a "favorable organizational context" for the functioning of the support team.

The second phase is called "Strategy of joint efforts and the use of competencies". And this shows that it is not enough to have certain competencies and strive for something together, - without the first stage all the efforts of the team can be a false start, because 
only preliminary work involving thoughtfulness, adoption (with expert coaching) of joint decisions and agreed algorithm will allow to successfully implement existing competencies of teachers.

The 3rd phase - achievement of the set tasks by the team, actual implementation of team efficiency, which is specified as:

1) provision of services;

2) monitoring and evaluation of the success of the support team;

3) further increase the competence of each specialist, as well as the support team as a whole.

The structure of the program: the study of the presence of team interaction in the teachers' work regarding supporting of the children with SEN and readiness for such interaction as an introductory seminar, 5 training sessions, permanent support (systematic coaching, mentoring) in the presence of monitoring processes, evaluation of the program effectiveness.

Training sessions covered the following topics:

- "Basic principles of team interaction: accompanying a student with SEN technology".

- "The creation of prerequisites for productive interaction of teachers and internal conditions for the prevention of professional burnout: psychophysiological resources of the teacher: ways of normalization and maintenance of psycho-emotional state".

- "The development of teacher's emotional intelligence".

- The ability to define "SMART-goals (central component of CDP) as a mean of successive and sustainable development of a student's with SEN".

- "The monitoring of the Student's with SEN's adaptation state in the inclusive environment and his subsequent successful education".

The whole program lasted 8 months, October 2017 to May 2018. Before introducing the training program for the establishment of team interaction, an introductory seminar was held where the participants were informed about the goal, tasks, certain steps, the procedure for the implementation of diagnostic, and monitoring processes, expected results and format of the training. The training sessions were conducted during the first 2 months, in consideration of, on the background of work, which was already begun, on teaching and methodological support of teachers without interruption from professional activity. For each school, a trustee was assigned (12 curators participated in it, and two schools were accompanied by 5 the most experienced curators).

After the creation of escort teams and rules for team interaction, its boundaries, and feedback, it was started the direct support of students with SEN covering the following acts. 
Act 1 . The valuation of the student's development condition by all members of the support team (each specialist evaluates according to the parameters in which he is competent); systematization of data in order to identify the student's actual needs.

Teachers were taught collegially to determine the state of the student's development, and in accordance with Taba-Tyler's method according to which the formulation of goals for the development of a curriculum must precede the definition of needs (Läänemets, 2013).

Act 2. The formulation of the primary SMART goals in the educational process for this student. The determination of the educational services content (including additional educational services) in accordance with the student with SEN's needs.

An example of a co-ordinated collaboration of specialists on the SMART-goal for a student with autism (P., 7 years old): "When an adult appeals to P. with a question that involves an agreement or denial, the boy gives the sign in a socially acceptable way (with a proper gesture) and he does this in 8 cases of 10 ".

That goal was set for six months. After the formulation of this goal, the function of each participant of the support team was distributed to achieve it.

Act 3. The creation of IEP for a student, the determination of the place, role and working mode of each specialist in the strategy developed for its intensive help.

The work around CDP creates an opportunity for effective collaboration between teachers, parents, special teachers, and students with SEN in order to improve the educational process.

Act 4. The creation of supportive, stimulating, and developing conditions in the educational institution where this student is studying (the implementation of the "Class Management" technology). As the "Class Management" technology is based on a holistic analysis of the children's needs, and the goals of their education, it involves the development of a methods, techniques, and tools system for meeting these needs.

Act 5. The implementation of educational activities (among them there are system rehabilitation services) for a child with SEN, in compliance with the settled purposes and objects in view of its development. By making coaching of the supporting teams, experts-mentors taught the specialists and parents to promote the development of students with SEN in life competence and social adaptation, to create conditions for him to make independently purposeful educational activity, to orientate themselves in daily routine, to become more mature and self-confident.

Act 6 . The monitoring and rating of the dynamics of the student's successful development: purposes, education and upbringing (as necessary) conditions adjustment.

We taught to make evaluation of the student for three times - at the beginning, in the middle, and at the end of the year by the methods that are intended for this purpose.

For example, for children with autism, it may be PEP-3, Leiter-3, questionnaires, etc.

Act 7. The reflection as the success of each support team participant activity and team activities as a whole. The formulation of ways to improve this activity and cooperation 
conditions between colleagues and parents. It was found that in the motivational profile of teachers is dominated by the focus on activities that will require:

- achieving results in terms of correction, compensation, habilitation, overcoming abnormalities in the psychophysical development of a child with special educational needs;

- focus on novelty, as the modern Ukrainian school is in a state of reform, which involves many innovations, in addition, a successful specialist of the XXI century must constantly improve their professional competence and find new effective innovative correctional and developmental methods of teaching, education, and development of children with special education. needs;

- leadership, expert support, pedagogical coaching to create an inclusive educational space, which provides teacher support and systematic support of personal and professional development of inclusive classroom teachers;

- teamwork with professionals and parents, which involves knowledge of teamwork strategies; technologies of joint decision-making regarding the process of education, upbringing and development of the child with teachers and parents; establishing effective partnerships with families; providing individual support for a child with special educational needs, which is possible provided that a trusting relationship is established.

\section{The completion stage: repeated empirical study to analysis the effectiveness of the created and implemented program.}

It was carried out using the methods, applied before their training: "TOM", "ISSA Tool" methods, as well as an interview, which specified the position of the "ISSA Tool" method.

As a result of conducting the teacher's competence study about the teamwork to accompany Students with SEN, it was found out that teachers have significantly increased their awareness and skills in team cooperation with students, their parents, and colleagues.

Thus, the TOM method revealed a significant improvement in such teacher's characteristics as: "Motivational commitment on to achievements" and "Motivational commitment on novelty". Thus, according to the commitment on achievements, the prevailing was not the average, but the high level, and 5,3\% of the teachers achieved even a "very high" level. It is clear that the situation with the motivational commitment on the novelty has fundamentally changed: available training "extremely low" indicators did not show any participant, instead of they showed the "extremely high" results. At the significant level, the results that have reached the "average and high level" also grew. And this shows that teachers have become more uninhibited; they began to use the spontaneity and creative manifestations; they have a desire to perceive a new one (knowledge, approaches, perspectives of vision); the awareness of the value of what is changing; the desire to change themselves.

The "ISSA Tool" method revealed a significant improvement in teachers' professional growth indicators. We will focus on those target areas (criteria) which have made the greatest changes (they were not so much improved as developed). 
In the interview with teachers, they admitted that the ability to communicate productively with the families was a great discovery for many of them. Next, there are quotes from the most interesting and most expressive interviews conducted with teachers. The 1st teacher shared her thoughts: "How many years have I not used the resource including mutual discussion and decision-making with parents; I was a self-reliant person. Now I felt how this facilitates the situation in the class". The 2nd teacher said: "When you discuss with parents, students, and other teachers what you invented by yourself, you hear such an interesting development of your ideas, which you even would not have thought about".

Concerning the "Developing environment" target industry it should be said that teachers appreciated the mastering of new opportunities very well: the ability to create an attractive, stimulating, supportive environment for all children: "We have not been taught neither at university nor in advanced training courses how to use the resources of the environment appropriately, to be able to adjust them to educational tasks" (the 3rd teacher); "I want to develop further in this direction and to be able to apply the ability to create a developing space" (the 4 th teacher).

According to the "Methods of training" criterion, teachers appreciated highly their obtained ability to understand the appropriate approaches to children with different educational needs, actively engage them in the practice of their work. So, the 5th teacher expressed her satisfaction about owning education methods that contribute to the emotional and social development of both children with SEN and other (normal) children. The 6th teacher shared her thoughts on how the usage of active education methods enabled her to influence positively the discipline: "We need to think more about the lesson, but given lesson is more interesting and my pupils and I get a real pleasure, while pupils remember the necessary material better and can use it in their lives".

As far as this research was aimed at revealing how the ability to work fully in team cooperation mode influence on the effectiveness of the providing the SEN support by educational staff in an educational institution, but important for our analysis were the changes that have taken place regarding the directly connected with these students education target "Inclusion" industry. After the implementation of this target industry education program, the following results were achieved: there was no indicator at the "unsatisfactory practice" level; "Good start" level was demonstrated by $52 \%$ of teachers, "Quality work practice" level included 32\% of the teachers, "How to move forward" level (this level was absent before training) included $16 \%$ of teachers.

\section{Discussion and conclusion}

Today there is a typical situation when teachers of inclusive classes do not coordinate between them the goals of a child with special needs development, they use different procedures, methods and means for his supporting; they do not find the correct balance 
between education and rehabilitation services for children with special needs; they do not conduct the monitoring of supporting process. It has been conducted the socio-psychological educational training for inclusive classes teachers based on the Richard Hackman's model of effective team management, aimed at assimilating the stages of getting success in supporting students with special needs.

Thus, it was found that in order to the teachers of inclusive educational institutions can be succeed in the process of supporting children with special needs, they must be masters in team interaction technology. According to the monitoring of questionnaires of the teachers, it is clear that their obtained skills enabled to create a real support team (headed by the coordinator), which is purposefully, consistently, consistent with the distribution of functions among all the members of a command. Important is the ability of a team to make the case development plan (CDP), an interdisciplinary support organically at each stage which involves collegiate assessment of its strong strengths and needs, the definition

of priority purposes, their formulation, the functions division of their achievement, the creation of the appropriate educational environment, monitoring and evaluation of the development of children with SEN and the estimation of the escort team. Nevertheless, conditions for the success of the support team are the presence of a coordinator and the direct involvement of parents as equal participants in the child's educational process, which should be implemented in a variety of ways: in discussing the educational plan, the content and scope of interventions, decision-makings, synchronous development of SMART-goals at home, the initiation of a communication diary, monitoring.

So, to conclude it should be said that the proposed results confirm the benefits of developed socio-psychological measures of optimizing team management, interaction, and increasing readiness for cooperation. A joint activities and the partnership of all team members has contributed to improving the learning and development of students with SEN, and in the general atmosphere in a class that is conducive to the development of all the students, and at the level of teacher's professional, interindividual and individual levels.

\section{References}

Al-Azawei, A., Parslow, P., \& Lundqvist K. (2017). The effect of universal design for learning (UDL) application on e-learning acceptance: A structural equation model. International Journal of Inclusive Education, 21 (8), 54-87. Retrieved from: https://files.eric.ed.gov/fulltext/ EJ1155806.pdf

Blecker, N. S., \& Boakes, N. J. (2010). Creating a learning environment for all children: are teachers able and willing? International Journal of Inclusive Education, 14 (5), 435-447.

Bateman, B., \& Herr, C. (2006). Writing measurable IEP goals and objectives (2nd ed.). USA: Attainment Co In. 
Boser, K., Goodwin, M., \& Wayland S. (2014). Technology tools for students with autism: innovations that enhance independence and learning (1st ed.). U.S. and Canada: Brookes Publishing.

Capp, M. J. (2017). The effectiveness of universal design for learning: a meta-analysis of literature between 2013 and 2016. International Journal of Inclusive Education, 21 (8), 791807. doi: 10.1080/13603116.2017.1325074

Carrero, K. M., Lewis, C. G., Zolkoski, S., \& Lusk, M. E. (2014). Research-based strategies for teaching play skills to children with autism. Beyond Behavior, 23 (3), 17-25. Retrieved from: https://www.researchgate.net/publication/273460128_Research_Based_Strategies_for_ Teaching_Play_Skills_to_Children_with_Autism

Corps, P. (2008). Classroom Management. Washington: Information Collection and Exchange.

Gudonis, V., \& Klopota, Y. (2017). Features of interpersonal interaction of blind and visually impairedyouth with student group. Pedagogika, 125 (1), 132-142. Retrieved from: http:// dx.doi.org/10.15823/p.2017.10

Hackman, J. R. (2002). Leading teams: setting the stage for great performances. Boston: Harvard Business School Press.

Hattie, J. (2009). Visiblelearning: A synthesis of over 800 meta-analyses relating to achievement. London: Routledge. Retrieved from: https://visible-learning.org/2017/05/video-john-hattiecollaborative-impact

İlik, Ş. Ş., \& Sarı, H. (2017). The training program for individualized education programs (IEPs): Its effect on how inclusive education teachers perceive their competencies in devising IEPs. Educational Sciences: Theory \& Practice, 17, 1547-1572. http://dx.doi.org/10.12738/ estp.2017.5.0424

Jucevičienè, P., Vizgirdaite, J., Alexander, H. (2018). Accessibility and inclusion in higher education: Implementing international imperatives in national and institutional contexts. Pedagogika, 130 (2), 46-63. http://doi.org/10.15823/p.2018.21

Klopota, Y., \& Klopota, O. (2017). Peculiarities of interpersonal cooperation of youth with different vision level. New Educational Review, 48 (2), 227-238. Retrieved from: http://www. educationalrev.us.edu.pl/e48/a18.pdf

Klopota, Y., Klopota, O., \& Gudonis V. (2019). Socio-psychological training for readiness for interaction in professional activity of employers and specialists' with blindness. Pedagogika, 134 (2), 224-236. https//ejournals.vdu.lt/index.php/Pedagogika/article/vew/792

Kurth, J., \& Foley J. (2014). Reframing teacher education: preparing teachers for inclusive education. Inclusion, 2 (4), 286-300.

Läänemets, U., \& Kalamees-Ruubel. K. (2013). The Taba-Tyler rationales. Journal of the American Association for the Advancement of Curriculum Studies, 9 (2), 1-12. https://doi.org/ 10.14288/ jaaacs.v9i2.187723. Retrieved from: https://ojs.library.ubc.ca/index.php/jaaacs/article/view/187723 Mesibov, G. B., \& Shea, V. (2010). The TEACCH program in the era of evidence-based practice. Journal of Autism and Developmental Disorders, 40 (5), 553-567.

Rotte, K. (2014). IEP Use by General and special education teachers. SAGE Open 4(2). doi: $10.1177 / 2158244014530410$ 
Stroggilos, Xanthacou. (2006) Collaborative IEPs for the education of pupils with profound and multiple learning difficulties, European Journal of Special Needs Education, 21 (3), 339-349. http://dx.doi.org/10.1080/08856250600810872 19.09.2010_

Strogilos, V., Avramidis, E., Voulagka, A., \& Tragoulia, E. (2018). Differentiated instruction for students with disabilities in early childhood co-taught classrooms: types and quality of modifications. International Journal of Inclusive Education, 1-23. https://doi.org/10.1080/1 3603116.2018.1466928. Retrieved from: http://www.tandfonline.com/doi/full/10.1080/0885 6257.2016 .1141512

Vygotsky, L. S. (1991). Pedagogical Psychology. In Davydov, V.V. (Ed.), L.S. Vygotsky. Educational Psychology, 118. Moscow: Pedagogika.

Wong, H. K., Wong, R. T., Jondahl S. F., \& Ferguson, O. F. (2014). The classroom management. Denton, Texas: Harry K. Wong Pubn.

\title{
Mokytojų, ugdančių specialiuju poreikių vaikus, bendradarbiavimas inkliuzinès aplinkos kūrimo kontekste
}

\author{
Tetiana Skrypnyk ${ }^{1}$, Olena Martynchuk ${ }^{2}$, Olha Klopota ${ }^{3}, V_{y t a u t a s}$ Gudonis ${ }^{4}$, Nataliia Voronska
}

1 Kijevo Boriso Grinčenkos universitetas, Humanitarinių mokslų institutas, Bulvarno-Kudriavska g. 18/2, UA-04053 Kijevas, Ukraina, dr.skrypnyk@gmail.com

2 Kijevo Boriso Grinčenkos universitetas, Humanitarinių mokslų institutas, Bulvarno-Kudriavska g. 18/2, UA-04053 Kijevas, Ukraina, o.martynchuk@kubg.edu.ua

3 Khortytsia nacionalinè akademija, Naukove Mistechko g. (Khortytsia sala) 59, UA-69017 Zaporožè, Ukraina, oa-klopota@ukr.net

4 Šiaulių universitetas, Edukologijos institutas, P. Višinskio g. 25, LT-76353 Šiauliai, Lietuva, vytautas.gudonis@su.lt

5 Zaporožès nacionalinis universitetas, Zhukovskogo g. 66, UA-69600 Zaporožè, Ukraina, natalyvoronska@ukr.net

\section{Santrauka}

Šio tyrimo aktualumą lemia tai, kad pastaruoju metu vis daugiau tėvų, auginančių specialiųjų poreikių vaikus, dažniau renkasi ne specialiąsias, o bendrojo lavinimo mokyklas. Vis dèlto dauguma mokytojų, dirbančių su šiais vaikais, dèl žinių stokos susiduria su sunkumais. Tyrimo tikslas - parengti ir aprobuoti ugdymo proceso dalyvių - pedagogų, specialistų, tèvų - darbo komandoje kompetencijų optimizavimo programą, dirbant su specialiųjų poreikių vaikais bendrojo ugdymo mokyklose. Tyrime dalyvavo keturių miestų 17 ugdymo įstaigų 152 pedagogai. Respondentai atrinkti atsitiktinès atrankos metodu. Didžioji dalis tiriamųjų (121; 79,6 proc.) buvo pedagogai: vieni turèjo darbo su specialiųjų poreikių vaikais patirtị, kiti žinojo, kad tokie vaikai artimiausiu metu ateis i jų klases. Šis tyrimas parodė, kad efektyvus komandinis darbas (mokytojai, specialistai, tėvai) yra veiksminga priemonė sprendžiant iškilusias problemas 
bendrojo lavinimo mokykloje. Buvo vykdoma socialinè-psichologinè švietimo programa „Mokytojų, dirbančių inkliuzinèje aplinkoje, komandinio darbo bendradarbiavimo strategijos“. Ši programa pagrịsta Hackman efektyvios organizacijos valdymo modelio teorija. Šiuo atveju tikslas buvo įsisavinti sèkmès etapus padedant specialiųjų poreikių mokiniams mokytis ir tobulèti. Gauti rezultatai patvirtina sukurtų sociologinių-psichologinių priemonių rinkinio, skirto optimizuoti komandinị valdymą, sąveiką ir didina inkliuzinių ugdymo ịstaigų pedagogų pasirengimo bendradarbiauti naudą. Buvo įrodyta, kad pedagogai gali sèkmingai padèti vaikams, turintiems specialiųjų poreikių, pritaikydami sèkmingo komandinio bendradarbiavimo modelị bei pasitelkdami konsultuojamojo ugdymo mokymus. Taip pat buvo nustatyta, kad inkliuzinių mokyklų mokytojai, norèdami sẻkmingai padèti specialiųjų poreikių vaikams, turi būti komandinio bendradarbiavimo strategijų valdymo meistrai. Kita vertus, savo igytomis kompetencijomis jie sukūrẻ patikimą palaikymo komandą, kuriai vadovavo koordinatorius, padèjęs kryptingai, nuosekliai kurti inkliuzinę aplinką mokymo(si) procese. Bendra visų komandos narių veikla ir partnerystė padejo pagerinti mokinių, turinčiu specialiųjų poreikių, mokymąsi ir tobulejimą, psichologinis klimatas klasėse tapo komfortiškesnis, išaugo ugdymo proceso dalyvių darbo komandoje kompetencijų lygis.

Esminiai žodžiai: mokytojo kompetencija, inkliuzija, specialiuju poreikių vaikai, bendradarbiavimas komandoje.

Gauta 20200216 / Received 16022020

Priimta 20200707 / Accepted 07072020 